\title{
DROSOPHYLLUM LUSITANICUM L.
}

Nigel Hewitt-Cooper • The Homestead • Glastonbury Road • West Pennard • Somerset, BA6 8NN •UK・sales@hccarnivorousplants.co.uk

Keywords: cultivation, Drosophyllum lusitanicum.

Regarded by many as the "odd man out" amongst carnivorous plants, Drosophyllum lusitanicum is one of those species not readily grown in cultivation, but which is surprisingly easy when a few simple rules are adhered to.

It produces long linear leaves to approximately $20 \mathrm{~cm}$ in length, which taper at their apex to a point. The long-lived leaves are held erect at first, and gradually lower to horizontal, finally resting at ground level where they die back, giving the plant a dome-like appearance. The base of the plant is skirted in the remains of the old leaves. The outer facing surface of the leaves is covered in numerous red stalked, mushroom-shaped glands which are topped with a droplet of mucilage (Fig. 1 \& Front Cover). The red coloration of these glands is a stark contrast to the vibrant green of the leaves. There are also numerous sessile glands on the leaf surface from which digestive enzymes are released. This plant is unique in being one of only two plants to have leaves which unfurl facing outwards from the center of the growth point, rather than facing inwards as a fern does. This phenomenon is known as outward circinate vernation, a characteristic shared only with a couple of Byblis species.

The leaves are arranged in such a way as to resemble the growth point of a pine (Pinus), giving rise to one of its common names, the Portuguese Dewy Pine. Mature plants produce a strong honey aroma which is used as an attractant, and which on plants outside, is extremely effective as the leaves can be almost black with the carcasses of dead flies.

When an insect lands on a leaf, the mucilage detaches from the stalked glands, adhering to the
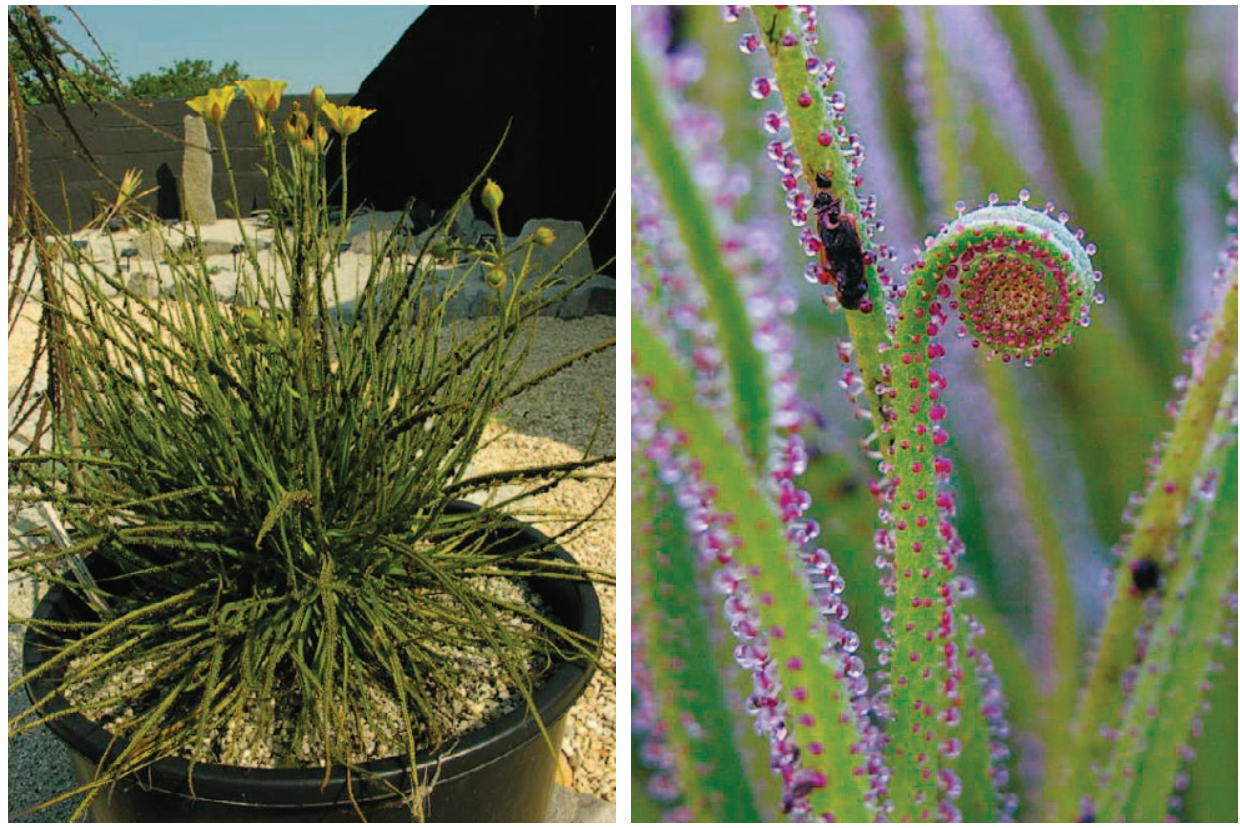

Figure 1: Mature Drosophyllum lusitanicum (left) and unfurling leaf (right). 

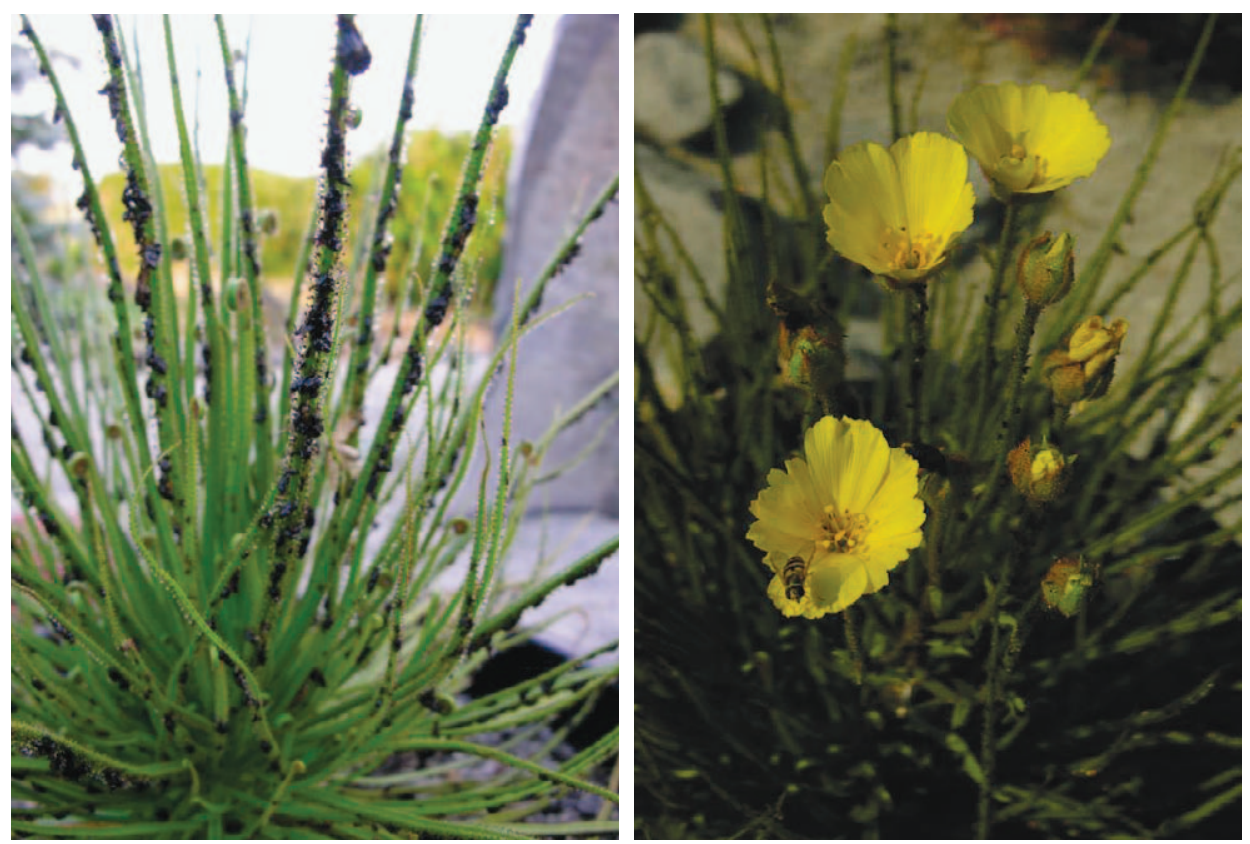

Figure 2: Captured prey (left) and open flowers (right).

animal's exoskeleton. As it struggles to escape it makes contact with numerous glands, each depositing another droplet of glue until the insect's exoskeleton is coated and it suffocates. Digestive enzymes are then released from the sessile glands which break down the soft element of the animal, leaving only the chitinous remains (Fig. 2).

In July and August flowering commences, with the flowers produced atop a thick glandular stem to $30 \mathrm{~cm}$ in height, and circular in cross section. The calyx lobes are also glandular. The stunning bright yellow 5-petalled flowers are approximately $2.5 \mathrm{~cm}$ in diameter, and open for 3-4 days (Fig. 2).

Once pollinated, the corolla is shed and the seeds develop in a conically triangular-shaped, translucent green seed pod which grows to about $1.25 \mathrm{~cm}$ in length, and is held upright (Fig. 3). When mature in October, the capsule splits longitudinally along the 5 seams to expose $15-20$ pyriform seeds, each about $3 \mathrm{~mm}$ in length (Fig. 3).

When a single growth point flowers, it does not leaf again, and is taken over by side shoots.
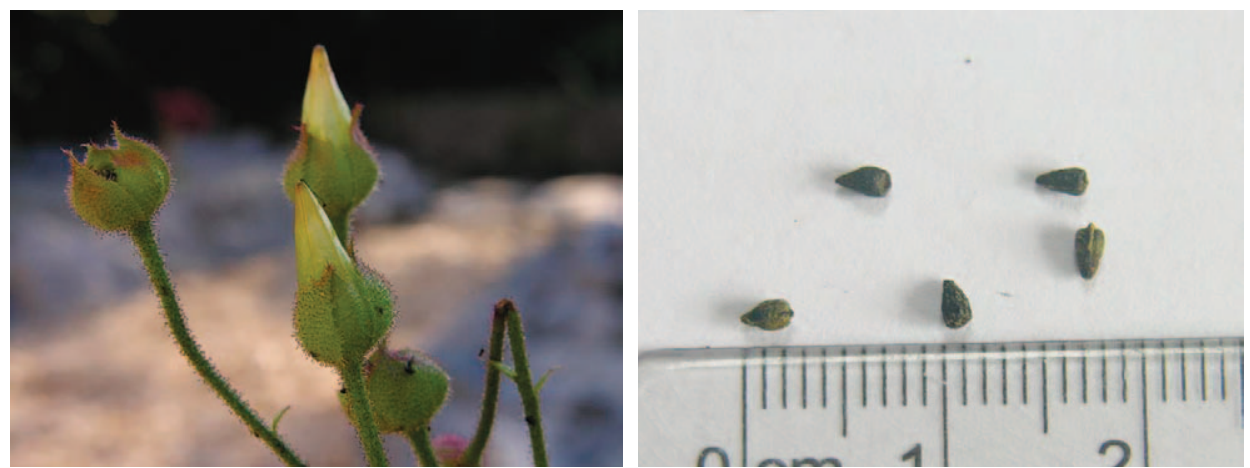

Figure 3: Conical seed heads (left) and seeds (right). 
The natural habitat of this plant is southern Spain, western Portugal, and northern Morocco, and it is somewhat different to many other carnivorous plants, with a preference of dry stony hillsides with comparatively little rainfall.

The plant is long-lived and over time forms a thick stem, and must have a substantial root system to penetrate deep into the substrate in search of moisture, which I feel is a key to long-term cultivation.

I first grew this plant in the mid-1980's, the original plant living for about 3 years, and indeed over the years have grown Drosophyllum many times, but found that each would live only 2 years before flowering and dying. Considering the substantial bulk of wild plants, one can surmise that they live for considerably longer, so there must be a method by which the longevity can be extended.

My early attempts at cultivation were using the so-called Slack method, whereby a small clay pot is set in a larger pot of the same type (Slack 1986), which I felt was too restrictive for the plant as the roots can only enter the larger container via the small drainage hole. With this in mind I started germinating seeds in those small fiber pots, which I then set in a large $(20 \mathrm{~cm})$ clay pot, the thinking being that the roots would not be as restricted, but still found that the plants would live only 2 years.

Whilst considering the wild conditions of the natural habitat, and seeing habitat photographs (McPherson 2008), I came to the conclusion that the roots are still too restricted so I exchanged the large clay pot for a 10 liter black plastic container pot with a diameter of $26 \mathrm{~cm}$, and a depth of $22 \mathrm{~cm}$. Also considering the arid, stony soil conditions, I chose to use cornish grit as a medium, with the addition of a handful of coarse lumps of peat moss to help maintain a small amount of moisture.

Still using the fiber pots for germination, I transferred a young $7.5 \mathrm{~cm}$-tall seedling in to the container pot in the summer of 2010, allowing the plant to establish over the cooler winter months in a greenhouse with a minimum temperature of $7^{\circ} \mathrm{C}$. Once the danger of frost was over, the pot was lifted outside to a full sun position for the summer, where it received virtually no water (except during an exceptionally dry spell), apart from the natural rainfall. By July the plant was some $35 \mathrm{~cm}$ tall, with many leaves, and certainly benefiting from the abundance of insects to be found outside, with the leaves turning almost black with carcasses. It's interesting to note that the aroma produced by the plant can be detected from up to 3 m away.

I move the plant back to a frost-free location in the autumn, though I suspect a light frost will do little damage.

Propagation of this plant is by seed, which germinates easily, and has a long viability (especially if refrigerated). I have germinated 5-year-old seeds with no problems, and have heard of older seed remaining viable. I sow them in the small fiber pots mentioned earlier, which are about $6 \mathrm{~cm}$ in diameter in a 50:50 mix of peat moss and silver sand, and cover them to a depth of about $5 \mathrm{~mm}$. I sow a single seed in each pot, and stand them in a tray of rain water in full sun. Germination should take 4-6 weeks. Keep the young plants in this position until they are about $6 \mathrm{~cm}$ tall, at which time they can be transplanted into a large container pot as described above. I now prefer plastic pots as they do not dry as rapidly as clay, and therefore the frequency of watering is minimal, especially in a damp location such as Somerset.

Outdoor cultivation of this plant appears to work well during the summer and certainly in a position of full sun when the plant will become less lax and more compact than those grown under glass, more closely resembling wild plants.

Seed kits of this fascinating plant are sometimes available from www.hccarnivorousplants.co.uk

\section{References}

Slack, Adrian. 1986. Insect-eating plants and how to grow them. Alphabooks Ltd, Sherborne, Dorset, England. 172 p.

McPherson, Stewart. 2008. Glistening Carnivores: The Sticky-Leaved Insect-Eating Plants. Redfern

Natural History Productions, Poole, Dorset, England. 392 p. 


\section{CARNIVOROUS PLANT NEWSLETTER}

Journal of the International Carnivorous Plant Society

Volume 41, No. 4

December 2012

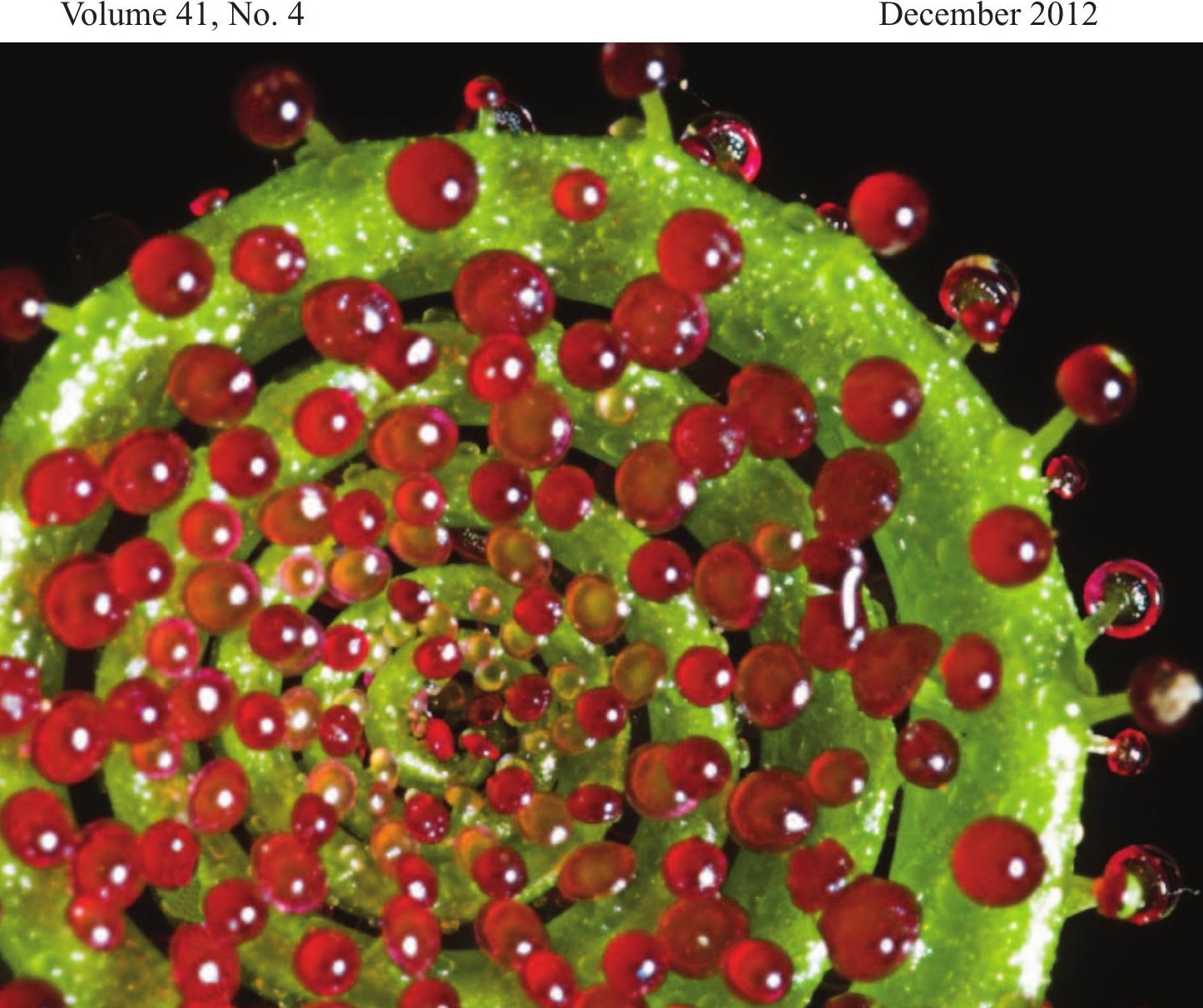

$\bullet$. 


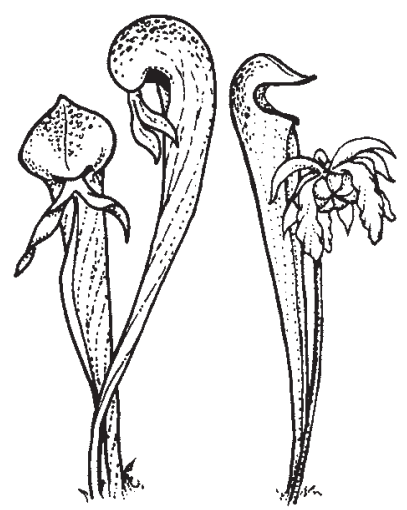

\section{CARNIVOROUS \\ PLANT \\ NEWSLETTER}

Journal of the International

Carnivorous Plant Society

www.carnivorousplants.org

Volume 41, Number 4 December 2012

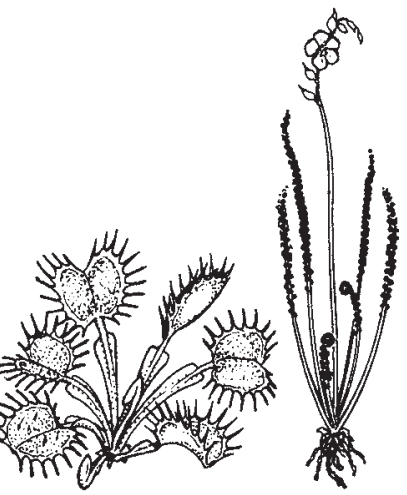

Front Cover: Unfurling Drosophyllum Iusitanicum leaf spiral. Photo by Barry Rice. Article on page 143.

Back Cover: A comparison of Roridula gorgonias (left) and Roridula dentata (right). Photo by Nigel Hewitt-Cooper. Article on page 146.

Carnivorous Plant Newsletter is dedicated to spreading knowledge and news related to carnivorous plants. Reader contributions are essential for this mission to be successful. Do not hesitate to contact the editors with information about your plants, conservation projects, field trips, or noteworthy events. Advertisers should contact the editors. Views expressed in this publication are those of the authors, not the editorial staff.

All correspondence regarding dues, address changes and missing issues should be sent to the Membership Coordinator at the ICPS. Do not send such correspondence to the editors. Checks for subscriptions should be made to the ICPS in US funds. Dues for 2013 are \$35 for the first year of membership; renewals are \$30 per year.

ICPS, Inc.

2530 Patra Drive

Richmond, CA 94803, USA

icps@carnivorousplants.org

President Michael Baldwin, michael@carnivorousplants.org

Vice President_Marcel van den Broek, marcel@carnivorousplants.org

Secretary

Treasurer

Cindy Slezak, cindy@carnivorousplants.org

Board Member

Richard Myers, richard@carnivorousplants.org

Board Member

Bob Ziemer, bob@carnivorousplants.org

Board Member

Jan Schlauer,jan@carnivorousplants.org

Seed Bank Manager

Brian Barnes, Conservation Director, brian@carnivorousplants.org

John Brittnacher, john@carnivorousplants.org (see seed bank ad in this issue)

Editors:

Managing Editor_Bob Ziemer, bob@carnivorousplants.org

Science Editor

Science Editor

Editor

Jan Schlauer,jan@carnivorousplants.org

Fernando Rivadavia, fernando@carnivorousplants.org

Barry Rice, barry@carnivorousplants.org

Date of effective publication of the September 2012 issue of Carnivorous Plant Newsletter: 31 August 2012.

The ICPS is the International Cultivar Registration Authority (ICRA) for the names of cultivated carnivorous plants according to the International Code of Nomenclature for Cultivated Plants. Send relevant correspondence to the ICPS, Inc.

Carnivorous Plant Newsletter is published quarterly in March, June, September, and December by the ICPS, Inc., 2530 Patra Drive, Richmond, CA 94803, USA. Periodicals postage paid at Richmond, CA and additional mailing offices. Postmaster: Send address changes to ICPS, Inc., PMB 322, 1564-A Fitzgerald Drive, Pinole, CA 94564-2229, USA. Printed by Allen Press, Inc., 810 E. 10th Street, Lawrence, KS 66044. Logo and masthead art: Paul Milauskas. (C) 2012 Carnivorous Plant Newsletter. All rights reserved. ISSN \#0190-9215 